\title{
Characterization of Lactobacillus brevis SCML 432 isolated from Meju in Sunchang and optimization of its culture conditions by statistical methods
}

\author{
Ji Won Seo, Hee-Jong Yang, Su-Ji Jeong, Myeong Seon Ryu, Gwangsu Ha, \\ Seong-Yeop Jeong, Do-Youn Jeong* \\ Microbial Institute for Fermentation Industry, Sunchang 56048, Korea
}

\section{순창 전통 메주 유래 Lactobacillus brevis SCML 432의 특성 및 통계학적 방법을 활용한 배양 조건 최적화}

\author{
서지원 · 양희종·정수지·류명선 · 하광수·정성엽·정도연* \\ (재) 발효미생물산업진흥원
}

\begin{abstract}
When used as a starter in the manufacture of Meju, it is expected that the quality of the soup products can be improved. In this study, we isolated Lactobacillus strain having possible safety and food-industrial benefits as a starter. Four hundred and seven isolates were screened from Meju, and chemically characterized for their antibacterial activity against Bacillus cereus, non-productivity of biogenic amine, and hemolysis. Eight of the isolates were selected upon chemical characterization, and their antioxidant and $\beta$-glucosidase activity was measured. Finally, we selected, and measured its enzyme activity and antibiotic resistance. Next, we investigated its cell growth, showed maximum biomass of $3.5 \mathrm{~g} / \mathrm{L}$ after $28 \mathrm{~h}$ of culture. The ingredients of the medium to improve biomass were selected using the Plackett-Burman design (PBD) and central composite design (CCD). The results obtained using PBD revealed molasses, yeast extract, and maltose to be significant factors determining the biomass of the L. brevis SCML 432 strain. The CCD was then applied with three variables found from PBD and the optimum values were predicted to be $5.5 \%$ molasses, $1.5 \%$ yeast extract, and $2.0 \%$ maltose, and the maximum biomass was predicted to be 11.2 g/L. Through model verification, we confirmed that the predicted and actual results were similar, with about 3.2-fold improvement in the biomass from $3.5 \mathrm{~g} / \mathrm{L}$ to $11.3 \mathrm{~g} / \mathrm{L}$ when compared to that obtained in basal medium. These results suggest that SCML 432 has high potential in the food industry as a starter.
\end{abstract}

Key words : biomass, Lactobacillus brevis, Meju, optimization, response surface methodology

\section{서 론}

전통발효식품은 우리나라 고유의 대두발효식품으로 우 리 조상들이 수백 년간 섭취한 식생활에 필수 조미식품으로 청국장, 된장, 간장 등이 널리 사용되고 있으며, 체내 흡수가

*Corresponding author. E-mail : jdy2534@korea.kr Phone : 82-63-650-2000, Fax : 82-63-650-9590

Received 9 May 2018; Revised 12 June 2018; Accepted 15 June 2018.

Copyright (c) The Korean Society of Food Preservation. All rights reserved.
부족하기 쉬운 필수 아미노산, 지방산 및 비타민 등이 풍부 하여 영양학적으로도 우수한 식품으로 알려져 있다(1). 대 두발효식품은 미생물 발효에 의해 다양한 생리활성 물질이 생성되며 이로 인해 항산화, 혈전용해, 혈압강화 등의 효과 가 있음이 밝혀졌으며, 특히 청국장 섭취 시 체내 혈전용해 능이 증가되어 대두발효식품의 섭취로 인해 다양한 혈관질 환을 예방 및 치료가 가능하다는 결과에 따라 최근에는 국내 전통식품에 대한 사회적 관심이 증가하고 있다(2). 하지만 대부분의 전통 장류는 소규모 영세한 업체 및 가정 에서 종류별, 지역별로 제조되고 있어 품질의 균질성이 낮 고, 발효 과정 또한 자연 발효로 진행되기 때문에 외부 환경 
에 노출되어 환경에 산재하고 있는 다양한 균이 혼재하여 제품의 품질 및 유해균에 의한 오염 등 다양한 문제점이 발생하고 있어 사회적으로도 최근 이슈가 되고 있는 실정이 다(3).

전통 장류에서 안전성에 관련하여 문제가 되는 유해요소 는 Bacillus cereus와 biogenic amine으로 이들에 의해 장류 의 안전성이 1 차적으로 좌우된다. 식품의 식중독을 일으키 는 B. cereus는 자연 환경에 널리 분포하여 증식하는 미생물 로 전통 장류에 가장 쉽게 오염되는 오염원 중 하나이며, B. cereus에 의해 생성되는 독소는 설사 및 구토를 유발하여 식품의 기준 및 규격으로 장류 내 허용 기준을 $1 \mathrm{~g}$ 당 $10^{4}$ $\mathrm{CFU}$ (colony forming unit) 이하로 규제하고 있다(4). 이에 국내 연구진은 식품 내 B. cereus의 저감화를 위해 물리적, 화학적 방법을 이용하여 유해균을 저해하기 위한 연구를 진행하였으며(5), 최근에는 B. cereus에 대하여 항균활성이 우수한 유용 미생물을 활용하여 식품 내 식중독 유해균을 저해하는 방법에 대한 연구가 집중적으로 이루어지고 있다 (6). Biogenic amine은 아미노산의 효소 반응에 의해 생성되 는 저분자 질소화합물로 미생물에 의한 발효 과정에서 흔히 발생하여 국내 전통식품의 경우 특히나 문제시 되고 있는 요소 중 하나이다. 콩과 같은 단백질원을 주로 사용하는 국내 발효식품이 발효되거나 부패되는 과정에서 주로 생성 되기 때문에 최근에 전통장류에서 biogenic amine으로 인한 문제점이 지적되고 있으며(7), 과량 섭취시 두통, 심혈관계 에 부정적 영향을 미치며, 일부 biogenic amine의 경우 $\mathrm{N}$-nitrosamine과 같은 강력한 발암물질로 전환될 수 있는 잠재성을 갖고 있는 것으로 보고되고 있다(8). 국내에서는 biogenic amine 저감화를 위해 감마선 조사법, 온도와 $\mathrm{NaCl}$ 농도에 의한 영향 조사, 식품 내 biogenic amine의 함량 조사 등 연구가 진행되고 있으며, 최근에는 비생성 발효 미생물 및 분해 미생물을 활용하여 biogenic amine의 제어를 위한 노력을 기울이고 있다(9).

유산균은 젖산을 생성하는 미생물로 식품 중 치즈와 같 은 유제품과 김치와 장류 같은 한국 전통발효식품에 많이 존재하고 있으며, 최근에는 프로바이오틱 소재로 섭취시 장내 미생물의 성질을 개선시켜 숙주에 유익한 영향을 주는 살아있는 미생물 단독 또는 복합균주로 알려져 있다(10). 특히 Lactobacillius 그룹은 유산, 초산 등의 유기산과 bacteriocin과 같은 단백질성 항균 물질을 생성하여 식중독 을 유발하는 B. cereus와 같은 유해세균의 증식을 억제하고, 세균총의 안정화, 비특이적 면역 증강 완화, 항암 및 항종양 등 유익한 기능성을 숙주에 대해 나타내는 것으로 알려져 있다(11). 또한 최근 식품 내 유해물질로 문제점이 제기되는 biogenic amine을 분해하거나 식품 제조 시 biogenic amine 을 생성하지 않는 유산균에 대한 연구도 활발히 진행되고 있으며, 이러한 기능성을 바탕으로 발효식품, 의약품, 화장 품 등 다양한 산업 분야에 활용되고 있다 $(12,13)$.
산업에 미생물을 적용하기 위해서는 무엇보다도 고농도 균체 배양이 중요시 되는데 이는 경제적 측면에서 매우 중요한 문제 중 하나이다. 배양 조건 및 배양 기간, 사용 배지 조성에 따라 미생물의 특성이 변화하고 배양에 따른 균체 성장 또한 바뀌게 되며, 가장 중요한 대사산물이 변하 게 된다. 특히 식품에 적용하기 위한 미생물의 산업적 적용 을 위한 경우에는 배지 성분의 선택 또한 중요한 문제점이 될 수 있다. 따라서 배양 조건, 배지 선정은 균체량 증가와 유용물질 회수의 용이성 등 목적에 따라 다양한 변수를 고려하여 선정해야 한다(14). 최근에는 다양한 변수에 대한 효과를 한번에 확인할 수 있는 반응표면분석법(response surface methodology, RSM)이 최적화를 위한 방법으로 많이 사용되고 있다. 반응표면분석법은 두 개 이상의 회귀변수 가 복합적으로 반응하는 변수에 영향을 미칠 때 반응 변수 가 이루는 표면에 대한 통계학적 분석을 기반으로 예측하는 방법으로 다양한 변수가 존재할 경우 매우 유용한 방법 중 하나이다(15).

따라서 본 연구에서는 발효식품에서 산업적으로 사용 가능한 유산균을 메주로부터 분리하고, 분리한 균주에 대 한 특성을 조사하여 가장 우수한 균주를 선별하며, 이를 산업화에 적용하기 위한 최적 배양 조건을 확립함으로 다양 한 식품 개발 및 산업에 이용하기 위한 기반을 마련하고자 연구를 수행하였다.

\section{재료 및 방법}

\section{유산균 분리 및 배양}

본 연구에서 사용한 시료는 전라북도 순창군 11 개면에서 전통 방법으로 제조한 메주 시료 약 180 여 종을 유산균 분리를 위한 균원 시료로 사용하였다. 각각의 시료 $1 \mathrm{~g}$ 을 멸균생리식염수 $9 \mathrm{~mL}$ 에 단계 희석하여 $\mathrm{MRS}$ agar(Difco ${ }^{\mathrm{TM}}$, Detroit, MI, USA) 배지에 $100 \mu \mathrm{L}$ 도말하여 $37^{\circ} \mathrm{C}$ 에서 48 시간 배양하였다. 각각의 배양한 미생물을 집락형태가 상이한 균주를 선별하여 순수 분리 하였으며, 선별 분리주는 $10 \%$ skim milk(Difco $\left.{ }^{\mathrm{TM}}\right)$ 에 재부유하고 $-80^{\circ} \mathrm{C}$ 에 보관하여 추후 연구에 사용하였다.

\section{Biogenic amine 분석}

선별 분리주의 발효 과정에서 biogenic amine이 생성되는 지에 대한 여부를 확인하기 위해 Jeong 등(16)의 방법에 따라 각각의 분리주에 대한 biogenic amine 분석을 수행하 였다. 분리주는 각 $1,000 \mathrm{ppm}$ 의 biogenic amine 전구체인 tyrosine(Sigma-Aldrich, St Louis, MO, USA)과 histidine (Sigma-Aldrich)이 함유된 MRS 액체 배지에 접종하여 $37^{\circ} \mathrm{C}$ 에서 24 시간 진탕배양 하였으며, 각각의 배양액은 15,000 $\mathrm{rpm}$ 에서 30 분간 원심분리 후 각 상등액을 회수하였다. 표준 
용액은 $0.01 \mathrm{~N} \mathrm{HCl}$ 에 약 $1 \mathrm{~g} / \mathrm{L}$ 가 되도록 제조한 후 0.1-100 $\mathrm{mg} / \mathrm{L}$ 의 농도로 단계 희석 후 검량 곡선을 작성하였다. 시료 용액과 표준용액 $0.5 \mathrm{~mL}$ 취한 후 내부표준용액 $1,7-$ diaminoheptane $(0.1 \mathrm{~g} / \mathrm{L}$, Sigma-Aldrich) $0.25 \mathrm{~mL}$ 을 첨가하 고, 포화 $\mathrm{Na}_{2} \mathrm{CO}_{3}$ (Sigma-Aldrich) 용액 $0.25 \mathrm{~mL}$ 과 $1 \%$ dansyl chloride(Sigma-Aldrich) $0.4 \mathrm{~mL}$ 을 첨가한 후 $45^{\circ} \mathrm{C}$ 에서 1시 간 동안 유도체화 하였다. 이후 $10 \%$ proline(Sigma-Aldrich) $0.25 \mathrm{~mL}$ 을 첨가하여 dansyl chloride(Sigma-Aldrich)를 제거 하고, ethyl ether(Samchun, Seoul, Korea) $2.5 \mathrm{~mL}$ 을 가하여 3 분간 진탕한 후 상등액을 취하였다. 이를 질소 농축기에서 완전히 증발시킨 후 잔여물을 acetonitrile(Duksan, Seoul, Korea) $0.5 \mathrm{~mL}$ 에 녹이고 $0.45 \mu \mathrm{m}$ syringe filter(Sartorius, Frankfurt, Germany)로 여과하여 HPLC 분석을 위한 시료로 사용하였다.

\section{항균 활성 측정}

식품내 식중독 유발 유해균에 대한 선별균주의 항균 활 성 여부를 조사하기 위해 대표적인 식중독 유발 균주인 Bacillus cereus에 대한 항균 활성은 Yang 등(9)의 방법에 따라 측정하였다. B. cereus KCTC 3624, KCCM 40935를 지시균주로 Nutrient broth(NB, Difco ${ }^{\mathrm{TM}}$ ) 배지에서 $37^{\circ} \mathrm{C}, 24$ 시간 배양 후 흡광도를 측정하여 일정한 농도( $\left.\mathrm{OD}_{660}, 0.4\right)$ 를 $0.8 \%$ agar를 함유한 NB soft agar 배지에 첨가하여 평판배지 를 제조하였다. 선별된 유산균은 $\mathrm{MRS}$ 배지에서 $37^{\circ} \mathrm{C}, 24$ 시 간 진탕 배양하여 $15,000 \mathrm{mpm}$ 으로 10 분간 원심분리 후 상등 액 취하여 $0.45 \mu \mathrm{m}$ syringe filter(Sartorius)로 제균한 뒤 6 $\mathrm{mm}$ well에 각각 분주하였다. 분주 후 $30^{\circ} \mathrm{C}$ 에서 24 시간 배양 하여 각가의 well 주변에 생기는 억제환의 크기를 측정하여 항균활성을 확인하였다.

\section{용혈성, 유해대사산물 및 유해효소 생성 분석}

선별 균주의 용혈성을 확인하기 위하여 blood agar base(MB cell, Seoul, Korea)에 5\% sheep blood(MB cell)를 첨가하여 배지를 제조하였다. 선별균주를 blood agar 배지 에 접종후 $37^{\circ} \mathrm{C}$ 에서 48 시간 배양하여 균주 주위로 생기는 환의 형태를 통해 용혈성을 확인하였다. 유해대사산물 indole, phenyl-pyruvic acid의 생성 여부를 확인은 먼저 tryptophan의 탈아미노화로 인하여 생성되는 indole을 선별 균주가 생성하는지 확인하기 위하여 각각의 분리주를 tryptone soya broth(TSB, Difco ${ }^{\mathrm{TM}}$ ) 액체배지에 접종하고 3 $7^{\circ} \mathrm{C}$ 에서 24시간 진탕배양 후 indole reagent dropper(Difco ${ }^{\mathrm{TM}}$, BBL Sensi-disc, Detroit, MI, USA)를 첨가하고 부드럽게 흔든 후 30초 내 배지 표면에 나타나는 색 변화로 indole 혈성 여부를 확인하였다. Phenyl-pyruvic acid는 phenylalanin agar(Fluka, Buchs, Switzerland) 배지에 분리주를 접종하여 $37^{\circ} \mathrm{C}$ 에서 24,48 시간 배양 후 $10 \%$ ferric-chloid(MB cell)를 3-4방울 첨가 후 균주 주위로 색의 변화로 통해 확인하였다.
또한, 유해효소인 urease는 Urea rapid test kit(MB cell)에 선별균주를 접종하고 vaseline oil(MB cell)을 첨가하여 산 소가 차단된 상태로 $37^{\circ} \mathrm{C}$ 에서 4-24시간 배양하며 색 변화를 확인하여 urease 생성여부를 확인하였다. $\beta$-glucuronidase 는 tryptone bile x-glucuronide(TBX, Oxoid, Hampshire, UK) 배지에 분리주를 접종하여 $37^{\circ} \mathrm{C}$ 에서 24,48 시간 배양 후 균주의 색 변화를 확인하여 $\beta$-glucuronidase 생성여부를 확 인하였다.

\section{항산화 활성 분석}

항산화 활성은 Ryu 등(17)의 방법에 따라 DPPH free radical 소거능으로 확인하였다. $100 \mu \mathrm{M}$ 2,2-diphenyl1-picryl-hydrazyl(DPPH, Sigma-Aldrich) ethanol 용액 $1 \mathrm{~mL}$ 에 $200 \mu \mathrm{L}$ 의 배양 상등액을 가하여 실온에서 30 분간 반응시 킨 후 UV/VIS spectrophotometer(SPECORD200, Analytic jena, Jena, Germany)로 $517 \mathrm{~nm}$ 에서 흡광도를 측정하였다. 대조구로는 MRS 배지를 사용하였으며, 아래 식을 활용하 여 DPPH free radical 소거능을 산출하였다.

$$
\text { DPPH free radical scavenging activity }(\%)=\left(1-\frac{\mathrm{A}}{\mathrm{B}}\right) \times 100
$$

A : Absorbance of DPPH solution with sample at $517 \mathrm{~nm}$

B : Absorbance of DPPH solution without sample at $517 \mathrm{~nm}$

\section{$\beta$-glucosidase 활성 측정}

선별 분리주의 항암 등에 관련되는 $\beta$-glucosidase 활성을 측정하기 위해 MRS broth에 exculin Iron agar(Difco $\left.{ }^{\mathrm{TM}}\right)$ 를 혼합하여 MRS-EI 배지를 제조하였다. 선별 유산균 균주를 MRS-EI 배지에 접종하여 $37^{\circ} \mathrm{C}$ 에서 48 시간 배양한 후 각각 의 콜로니 주변의 색 변화로 $\beta$-glucosidase 활성 보유 유무를 확인하였다.

\section{API ZYM kit을 이용한 효소활성 분석}

일반적으로 미생물의 경우 각각 고유의 유해 효소 및 유용 효소에 대한 억제와 생성에 대한 특성이 상이하게 된다. 따라서 선별균주의 효소활성을 확인하기 위하여 총 19 종의 각종 효소의 기질 이용성을 기초로 제작된 API ZYM kit(BioMerieux, Marcy-I'Etoile, France)를 사용하였 다. 선별 유산균을 MRS agar 배지에서 획선 도말하여 $37^{\circ} \mathrm{C}$ 에서 48시간 배양한 콜로니를 $2 \mathrm{~mL}$ suspension medium에 재부유하고, 5-6 McFarland로 탁도를 맞추어 각 tube에 60 $\mu \mathrm{L}$ 씩 분주하고 $37^{\circ} \mathrm{C}$ 에서 4 시간 배양한 후 $\mathrm{ZYM} \mathrm{A}$ 와 $\mathrm{ZYM}$ $\mathrm{B}$ 를 각 tube에 한 방울씩 떨어뜨리고 5 분간 실온에서 반응 시켜 색 변화로 각각의 기질 효소에 대한 활성 여부를 판독 하였다. 


\section{항생제 감수성 분석}

선별 균주의 항생제 감수성 여부를 판단하기 위하여 NCCLS(National Committee for clinical Laboratory Standards)의 디스크 확산법으로 실시하였다. 사용한 항생 제 디스크(BBL)는 amikacin(30 $\mathrm{\mu g}, \mathrm{AN})$, amoxicillin/

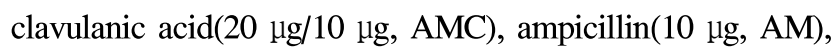

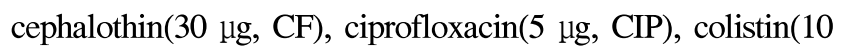

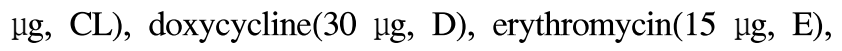
gentamicin(10 $\mu \mathrm{g}, \mathrm{GM})$, lincomycin(2 $\mu \mathrm{g}, \mathrm{L})$, kanamycin(30 $\mu \mathrm{g}, \mathrm{K})$, neomycin(30 $\mu \mathrm{g}, \mathrm{N})$, norfloxacin(10 $\mu \mathrm{g}, \mathrm{NOR})$, streptomycin $(10 \mu \mathrm{g}, \mathrm{S})$, tetracyline $(30 \mathrm{\mu g}$, TE), trimethoprim/ sulfamethoxazole $(1.25 \mu \mathrm{g} / 23.75 \mu \mathrm{g}, \mathrm{SXT})$ 등 16 종을 사용하 였다. 선별된 균주를 Mueller hinton broth(Merck, Darmstadf, Germany)에 접종하고 $37^{\circ} \mathrm{C}$ 에서 5시간 배양한 후 0.5 MacFarland(BioMerieux)로 맞춰 Muller-Hinton agar(Merck) 에 도말하고 30 분간 건조하여 16 종의 항생제 디스크를 올 린 후 $37^{\circ} \mathrm{C}$ 에서 24 시간 방치 후 각 항생제에 대한 억제환의 크기를 측정하고 CLSI 가이드라인에 따라 감수성과 내성 을 판정하였다.

최종 선별 균주의 균체량에 대한 time course profile 최종 선별 균주의 생육도 조사를 위하여 MRS 배지에서 배양하면서 균체 성장을 조사하였다. $37^{\circ} \mathrm{C}$ 에서 72 시간동안 $150 \mathrm{rpm}$ 으로 배양하여 분석하였으며, 4 시간 단위로 시료를 회수하여 각각을 균체량 측정을 위한 시료로 사용하였다.
배양액은 건조 균체량과 흡광도를 측정하여 생육곡선을 작성하였으며, 흡광도는 배양액 $1 \mathrm{~mL}$ 을 $13,000 \mathrm{rpm}$ 에서 30 분간 원심 분리 후 멸균증류수를 이용하여 3회 세척하고, $1 \mathrm{~mL}$ 의 멸균증류수에 재부유하여 흡광도를 측정하였다. 건조 균체량의 경우 $10 \mathrm{~mL}$ 의 시료를 $13,000 \mathrm{rpm}$ 에서 30 분 간 원심분리 후 3 회간 멸균증류수를 이용하여 세척하고 $80^{\circ} \mathrm{C}$ 에서 항량이 도달할 때까지 건조 후 균체 무게를 측정 하였다.

\section{Plackett-Burman design을 이용한 배지 성분 확립}

SCML 432의 균체 성장을 위한 배지 조성의 선별을 위해 Plackett-Burman design(PBD)을 실시하였다. Table 2와 같이 균체 성장 변수는 탄소원 6종(glucose, sucrose, maltose, lactose, fructose, molasses), 질소원 4종(GOS, yeast extract, tryptone, peptone), 무기질 3종 $\left(\mathrm{K}_{2} \mathrm{HPO}_{4}, \mathrm{KH}_{2} \mathrm{PO}_{4},\left(\mathrm{NH}_{4}\right)_{2} \mathrm{SO}_{4}\right)$, 기타 미량원소 2 종 $\left(\mathrm{MgSO}_{4}, \mathrm{MnSO}_{4}\right)$ 으로 15 개의 실험구를 구성하였다. 각각 성분은 2 가지 수준(high level(+)과 low level(-))으로 나누어 진행하였고, 설정값에 대한 농도는 탄 소원의 경우 중심값을 $17 \pm 13 \mathrm{~g} / \mathrm{L}$ 로 설정하였으며, 질소원 은 $12 \pm 8 \mathrm{~g} / \mathrm{L}$, 무기질 $6 \pm 4 \mathrm{~g} / \mathrm{L}$, 기타 미량원소 $0.6 \pm 0.4 \mathrm{~g} / \mathrm{L}$ 로 설정하였다. 모든 실험구는 3회 반복 측정을 통하여 수행하 였고, PBD 실험을 위한 실험 계획 및 분석은 Design expert 9.0(Version 9.0.3.1, Stat-Ease Inc., Minneapolis, USA) 프로 그램을 사용하여 분석하였다.

Table 1. Comparison of biochemical characterization for selected strains

\begin{tabular}{|c|c|c|c|c|c|c|c|c|c|}
\hline \multicolumn{2}{|c|}{ Strain no. } & SCML 199 & SCML 377 & SCML 379 & SCML 380 & SCML 432 & SCML 467 & SCML 504 & SCML 507 \\
\hline \multicolumn{2}{|c|}{ Identification } & $L$ brevis & L. brevis & L. brevis & L. brevis & L. brevis & L. sakei & L. brevis & L. brevis \\
\hline \multirow{2}{*}{$\begin{array}{l}\text { Antibacterial } \\
\text { activity (mm) }\end{array}$} & $\begin{array}{l}\text { B. cereus } \\
\text { KCTC } 3624\end{array}$ & 15 & 18 & 14 & 16 & 15 & 12 & 15 & 16 \\
\hline & $\begin{array}{c}\text { B. cereus } \\
\text { KCCM } 40935\end{array}$ & 15 & 14 & 14 & 16 & 17 & 17 & 15 & 16 \\
\hline \multirow{2}{*}{ Biogenic amine } & Tyramine & $\mathrm{NQ}^{1)}$ & ND & NQ & $\mathrm{ND}$ & ND & NQ & $\mathrm{ND}$ & NQ \\
\hline & Histamine & $\mathrm{ND}^{2)}$ & $\mathrm{ND}$ & $\mathrm{ND}$ & $\mathrm{ND}$ & $\mathrm{ND}$ & $\mathrm{ND}$ & NQ & NQ \\
\hline \multicolumn{2}{|c|}{ Haemolytic activity } & z-hemolysis & z-hemolysis & $\gamma$-hemolysis & $\gamma$-hemolysis & $\gamma$-hemolysis & $\gamma$-hemolysis & $\gamma$-hemolysis & z-hemolysis \\
\hline \multicolumn{2}{|c|}{ Indole } & -3) & - & - & - & - & - & - & - \\
\hline \multicolumn{2}{|c|}{ Phenylpyruvc acid } & - & - & - & - & - & - & - & - \\
\hline \multicolumn{2}{|c|}{$\beta$-glucuronidase } & - & - & - & - & - & - & - & - \\
\hline \multicolumn{2}{|c|}{ Urease } & - & $+^{4)}$ & + & + & - & - & + & + \\
\hline \multicolumn{2}{|c|}{$\begin{array}{c}\text { DPPH radical } \\
\text { scavenging activity }\end{array}$} & $12.51 \pm 0.17$ & $9.84 \pm 0.11$ & $6.70 \pm 0.18$ & $8.50 \pm 0.17$ & $27.15 \pm 0.19$ & $20.00 \pm 0.31$ & $20.97 \pm 0.45$ & $21.11 \pm 0.29$ \\
\hline \multicolumn{2}{|c|}{$\beta$-glucosidase activity } & $+++^{5)}$ & ++ & + & ++ & +++ & +++ & +++ & +++ \\
\hline
\end{tabular}

\footnotetext{
${ }^{11}$ Not quantified.

${ }^{2)}$ Not detected.

${ }^{3)}$ Negative effect.

${ }^{4}$ Positive effect.

${ }^{5}+++, 1.5-1.9 ;++, 1.0-1.4 ; \mathrm{ND},<1.0$
} 
Table 2. Plackett-Burman design with low and high levels of selected fifteen elements and response values

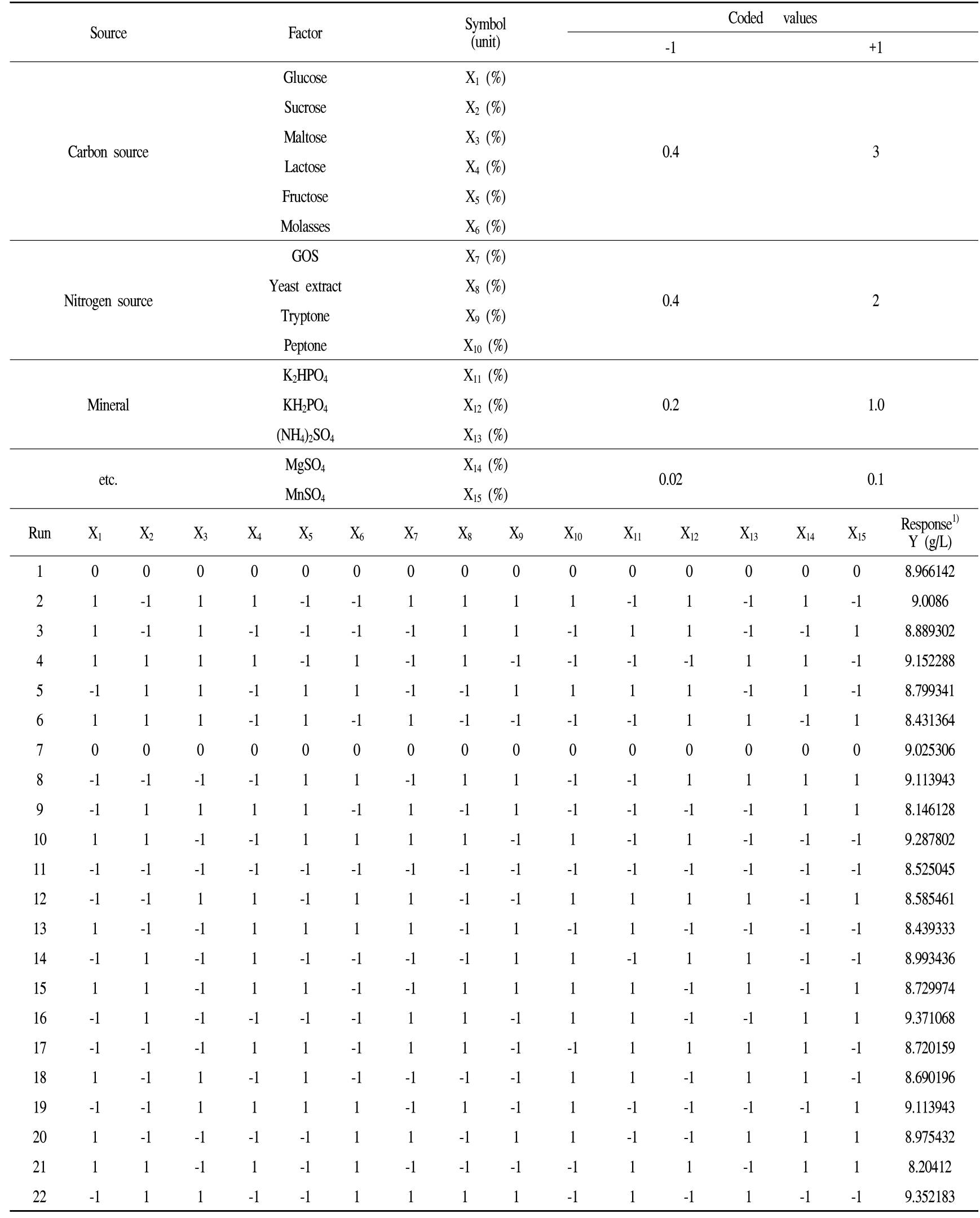

Dry cell weight by Lactobacillus brevis SCML 432 cultivated at $150 \mathrm{rpm}, 37^{\circ} \mathrm{C}$ for $28 \mathrm{~h}$ The experiments were carried out in triplicate. ${ }^{1}$ Response was dry cell weight from $L$ brevis SCML 432. 


\section{Central composite design을 이용한 배지 성분의 농도 최적화}

$\mathrm{PBD}$ 를 통해 최종 선별된 각 배지 성분의 최적 농도를 결정하기 위해 central composite design(CCD)을 이용하여 각각 배지 성분에 대한 농도 최적화를 진행하였다. Table 3 과 같이 독립 변수로는 molasses $\left(\mathrm{X}_{1}\right)$, yeast extract $\left(\mathrm{X}_{2}\right)$, maltose $\left(\mathrm{X}_{3}\right)$ 등 3 개의 성분을 요인 변수로 설정하였으며. 5 개의 수준에서 실험계획을 수립하였다. 앞서 확립된 배양 시간 및 $\mathrm{PBD}$ 를 통해 설정된 요인을 기반으로 실험을 진행 하였으며, $5 \%$ seed 배양액을 각각의 실험구에 접종하여 배양이 종료된 후 회수하고 건조 균체량을 측정하여 반응값 (Y)으로 사용하였다. 중심점 2개를 포함한 총 16개 구간에 실험을 실시하였으며, 각각의 독립 변수에 대한 종속변수 (Y, 건조 균체량)를 측정하여 그 값을 회귀분석 하였으며, 회귀분석 모델식은 다음과 같다.

$$
\begin{aligned}
Y= & \beta_{0}+\beta_{1} X_{1}+\beta_{2} X_{2}+\beta_{3} X_{3}+\beta_{11} X_{1} X_{1}+\beta_{21} X_{2} X_{1} \\
& +\beta_{22} X_{2} X_{2}+\beta_{31} X_{3} X_{1}+\beta_{32} X_{3} X_{2}+\beta_{33} X_{3} X_{3}
\end{aligned}
$$

Table 3. Central composite design with five levels of selected elements by the result of Plackett-Burman design and response

\begin{tabular}{|c|c|c|c|c|c|c|}
\hline \multirow{2}{*}{ Factor } & \multirow{2}{*}{$\begin{array}{c}\text { Symbol } \\
\text { (unit) }\end{array}$} & \multicolumn{5}{|c|}{ Coded values } \\
\hline & & -2 & -1 & 0 & +1 & +2 \\
\hline Molasses & $X_{1}(\%)$ & 1.0 & 2.5 & 4.0 & 5.5 & 7.0 \\
\hline Yeast extract & $\mathrm{X}_{2}(\%)$ & 0.5 & 1.5 & 2.5 & 3.5 & 4.5 \\
\hline Maltose & $\mathrm{X}_{3}(\%)$ & 0.5 & 2.0 & 3.5 & 5.0 & 6.5 \\
\hline Run & $X_{1}$ & $X_{2}$ & & $X_{3}$ & & $\begin{array}{l}\text { sponse }^{1)} \\
(\mathrm{g} / \mathrm{L})\end{array}$ \\
\hline 1 & -1 & -1 & & -1 & & 5.38 \\
\hline 2 & 2 & 0 & & 0 & & 13.38 \\
\hline 3 & 0 & 0 & & -2 & & 8.05 \\
\hline 4 & 1 & -1 & & 1 & & .04333 \\
\hline 5 & 0 & 0 & & 2 & & 046667 \\
\hline 6 & 1 & 1 & & 1 & & 11.16 \\
\hline 7 & 0 & 0 & & 0 & & 8.35 \\
\hline 8 & -1 & 1 & & 1 & & 6.11 \\
\hline 9 & 1 & -1 & & -1 & & 11.16 \\
\hline 10 & 0 & 2 & & 0 & & 8.23 \\
\hline 11 & 0 & -2 & & 0 & & 566667 \\
\hline 12 & -1 & -1 & & 1 & & 5.53 \\
\hline 13 & -1 & 1 & & -1 & & 4.53 \\
\hline 14 & 1 & 1 & & -1 & & 0.33667 \\
\hline 15 & -2 & 0 & & 0 & & 3.05 \\
\hline 16 & 0 & 0 & & 0 & & 8.34 \\
\hline
\end{tabular}
values

Dry cell weight by Lactobacillus brevis SCML 432 cultivated at $150 \mathrm{rpm}, 37^{\circ} \mathrm{C}$ for $28 \mathrm{~h}$. The experiments were carried out in triplicate.

${ }^{1)}$ Response were dry cell weight from $L$ brevis SCML 432.
여기서 $\mathrm{Y}$ 는 종속 변수이고, $\beta_{0}$ 은 절편, $\beta_{\mathrm{x}}$ 는 회계계수로 회귀분석을 위한 프로그램으로는 Design expert 9.0 (Stat-Ease Inc.)를 사용하였다. 최종 모델에 대한 검증 분석 을 위하여 평균과 표준편차 등의 기술통계량을 산출하였 고, 통계적 유의성 검증을 위해 SPSS20(SPSS Inc., Chicago, $\mathrm{IL}, \mathrm{USA}$ )을 이용하여 일원배치분산분석(one-way ANOVA) 을 실시하였다. 본 연구에 이용된 통계적 유의성 검증은 $\mathrm{p}<0.05$ 수준에서 수행하였다.

\section{결과 및 고찰}

\section{메주로부터 유산균 분리}

Lactobacillus 속 미생물은 전통 식품, 젓갈류 등 발효식품 에 많이 존재 하며, 유해세균의 증식을 억제하고 과민성대 장증후군에 효능이 있다고 보고되었다(18). 따라서 Lactobacillus 속 미생물을 분리하기 위해 전라북도 순창군 에서 전통방식으로 제조한 메주 약 180 종으로부터 육안으 로 미생물의 집락의 형태적 특징에 따라 약 407종의 분리주 를 1차 선별하였으며, MRS 액체배지에 접종하여 2일간 배양한 후 다음 연구 위한 시료로 사용하였다.

\section{분리주의 B. cereus에 대한 항균활성}

메주로부터 분리한 분리주 407종을 대상으로 식중독을 유발하는 병원성 미생물인 Bacillus cereus(KCTC 3624, KCCM 40935) 2종에 대한 항균 활성을 well diffusion 방법 을 통해 측정하였다. 선별 분리주 대부분 1 개 이상의 시험균 주에 대한 항균 활성을 보이는 것으로 확인되었고, 2 종의 유해미생물 모두에 대하여 항균 활성을 갖는 분리주는 107 종으로 확인되었다. 그 중 항균 활성이 SCML 199, SCML 377, SCML 379, SCML 380, SCML 432, SCML 467, SCML $504, \mathrm{SCML} 507$ 8종이 2종의 시험 균주에 대한 항균 활성을 지니며 활성 크기도 우수함을 확인하였다(Table 1). 일반적 으로 B. cereus는 세균성 식중독을 일으키는 유발균으로 알려져 있으며, 최근 식품에서 Bacillus 속 미생물을 이용하 여 미생물에 의해 생성되는 항균 물질에 의해 병원성 균주 를 억제하는 식품 보존제로 사용되고 있으며(19), 최근에는 Bacillus 이외에도 Lactobacillus 속 균주를 활용한 식품 병원 균을 억제하는 용도로 사용되고 있어 $(17,20)$ 이들과 유사하 거나 항균활성이 높은 균주 8종을 biogenic amine 및 유해효 소 등 생성능 분석을 위한 균주로 선별하였고, 8 종을 대상으 로 $16 \mathrm{~S} \mathrm{rRNA}$ 유전자 염기서열 분석을 통해 동정 한 결과 선별 분리주는 Lactobacillus brevis 7종과 Lactobacillus sakei 1종으로 동정되어 식품 내 사용 가능한 균주임을 확인 하였다. 


\section{Biogenic amine 함량}

최근 전통식품 중 콩을 주 원료로 하는 메주, 청국장, 된장과 같은 발효식품에서 biogenic amine이 아미노산 탈탄 산효소 활성을 갖는 미생물에 의해 두통, 복통, 알레르기 등 질병을 일으킨다고 보고되고 있으며 $(9,21)$, histamine의 경우 8-40 mg 이상 섭취시 두통 등 증상이 발생하고, tyramine의 경우 $100 \mathrm{mg}$ 이상 섭취시 중독 증상이 발생한다 고 보고되고 있다(22). 따라서 선별된 8종의 분리주를 대상 으로 biogenic amine 생성 유무를 조사하였으며, 그 결과 8 종의 분리주 모두 검출되지 않거나 정량되지 않는 인체에 무해한 수준 이하의 histamine과 tyramine이 생성되는 것을 확인하였으며, 특히 3종의 분리주 SCML 377, SCML 380, SCML 432가 전혀 생성되지 않는 것으로 확인되었다(Table 1). Biogenic amine 생성을 억제하기 위해 최근에는 비생성 균주 및 저감화 균주를 이용하여 발효 식품 등에 사용하고 있는 추세이며, Lactobacillus 속에 의해 biogenic amine 생성 억제 및 저감화에 대한 연구가 진행되고 그 결과 또한 보고 되고 있다 $(9,23)$. 따라서 선별 분리주 8 종 모두 향후 식품 등 발효를 통한 제품 개발 시 biogenic amine 비생성 균주로 유용하게 사용될 수 있는 가능성을 확인하였다.

\section{용혈성, 유해대사산물 및 유해효소 생성}

용혈성은 적혈구가 파괴되며 발생하는 정상적인 작용과 유전적 결함, 화학물질, 미생물에 의해 생성되는 독성 물질 에 의해 형성되는 비정상적 작용으로 나뉘며, 생체 내 용혈 현상은 주로 비장, 간장, 골세포 등에서 발생하며 비정상적 용혈 현상이 발생할 경우 적혈구의 산소운반 기능 장애로 인해 생체 내에 치명적인 결과를 가져온다(24). 따라서 선별 분리주 8 종을 대상으로 용혈성에 대한 조사 결과 비정상적 용혈성인 hemolysin을 생성하지만 적혈구 막을 파괴하지 않고 hemoglobin을 mehemoglobin으로 전환하여 콜로니 주 변이 녹색의 용혈대를 형성하는 a-hemolysis와 가용성 hemolysin에 의해 적혈구 막을 파괴하여 콜로니 주변이 투 명하게 되는 $\beta$-hemolysis가 모두 관찰되지 않았으며, 정상 적 용혈 현상에 속하는 $\gamma$-hemolysis의 활성을 나타내는 것 으로 확인되었다(Table 1). 다음으로 trytophanase에 의해 trytophane을 분해하여 생성되는 발암 관련 유해 물질인 indole과 phenyl-pyruvic acid, 발암에 관련하는 효소인 urease와 B-glucuronidase에 대하여 유해 효소 생성 여부를 확인하기 위한 실험을 진행하였으며, 그 결과는 Table 1 과 같다. 선별 분리주 8종에 대하여 indole과 phenyl-pyruvic

Table 4. Enzyme production profiles tested by API ZYM kit and antibiotic resistance of $L$. brevis SCML 432

\begin{tabular}{|c|c|c|c|}
\hline Enzymes & SCML 432 & antibiotic & SCML 432 \\
\hline Control & 1) & Cephalothin $(\mathrm{CF} / 30 \mu \mathrm{g})$ & $\mathrm{ND}^{3)}$ \\
\hline Alkaline phospatase & - & Neomycin $(\mathrm{N} / 30 \mu \mathrm{g})$ & $S^{4)}$ \\
\hline Esterase (C4) & $t^{2)}$ & Lincomycin $(\mathrm{L} / 2 \mu \mathrm{g})$ & $\mathrm{ND}$ \\
\hline Esterase lipase (C8) & + & Doxycycline $(\mathrm{D} / 30 \mu \mathrm{g})$ & SS \\
\hline Lipase (C14) & - & Tetracycline $(\mathrm{TE} / 30 \mu \mathrm{g})$ & $S$ \\
\hline Leucine arylamidase & + & Gentamicin $(\mathrm{GM} / 10 \mu \mathrm{g})$ & S \\
\hline Valine arylamidase & + & Colistin (CL/10 $\mu \mathrm{g})$ & $\mathrm{ND}$ \\
\hline Cystine arylamidase & - & Amocicillin/Clavulanic acid (AMC/20, $10 \mu \mathrm{g})$ & SS \\
\hline Trypsin & - & Ciprofloxacin (CIP/5 $\mu \mathrm{g})$ & ND \\
\hline a-Chymotrypsin & - & Streptomycin (D/10 $\mu \mathrm{g})$ & $\mathrm{ND}$ \\
\hline Acid phosphatase & + & Norfloxacin $(\mathrm{NOR} / 10 \mu \mathrm{g})$ & $\mathrm{ND}$ \\
\hline Naphol-AS-BI-phosphohydrolase & + & Kanamycin $(\mathrm{K} / 30 \mu \mathrm{g})$ & ND \\
\hline a-Galactosidase & + & Ampicillin $(\mathrm{AM} / 10 \mu \mathrm{g})$ & SS \\
\hline ß-Galactosidase & + & Erythromycin $(\mathrm{E} / 15 \mu \mathrm{g})$ & SS \\
\hline$\beta$-Galucuronidase & + & Amikacin (AN/30 $\mu \mathrm{g})$ & $\mathrm{ND}$ \\
\hline a-Galcosidase & - & Rimethoprim/Sulfamethoxazole(SXT/1.25, $23.75 \mu \mathrm{g})$ & ND \\
\hline$\beta$-Galcosidase & + & & \\
\hline $\mathrm{N}$-Acetyl- $\beta$-galcosaminidase & + & & \\
\hline a-Mannosidase & - & & \\
\hline a-Fucosidase & - & & \\
\hline
\end{tabular}

${ }^{1)}$ Negative effect.

${ }^{2}$ Positive effect.

${ }^{3}$ Not detected.

${ }^{4}$ SS, 1.6-2.0; S, 1.2-1.5 
acid, $\beta$-glucuronidase는 모두 생성되지 않는 것을 확인하였 으나, urease의 경우 SCML 377, SCML 379, SCML 380, SCML 504, SCML 507 등 5종에서 검출되었다. 최근에는 이러한 유해 효소의 위험성에 대한 문제점을 해결하기 위해 식품에 사용하는 발효 미생물의 유해 물질 생성여부에 대한 분석이 진행되고 있으며, 전통 식품에서 분리한 유산균의 경우 유해효소의 생성을 억제한다고 보고되어(17), 분리주 8 종에 대한 분석을 실시하여 3종의 분리주 SCML 199, SCML 432, SCML 467이 유해물질에 대한 안정성도 높은 균주임을 확인하였다.

\section{분리주의 항산화 활성}

체내 다양한 반응에 의해 생성되는 superoxide anion, hydrogen peroxide, hydroxyl radical과 같은 활성산소는 생 체 효소 및 단백질의 산화적 손상을 일으키게 되어 유전자 의 손상과 발암 등을 유발한다. 하지만 일부 유산균이 효소 적, 비효소적 방법을 통해 활성산소를 소거시켜 항산화 활 성이 증진되고 이로 인해 노화를 억제하는 중요한 역할을 한다고 알려지고 있다(25). 따라서 앞서 선별한 분리주 8종 을 대상으로 항산화 활성을 측정한 결과 SCML $432, \mathrm{SCML}$ $467, \mathrm{SCML} 504, \mathrm{SCML} 507$ 이 $20 \%$ 이상의 항산화 활성을 보였으며, SCML 432가 $27.15 \pm 0.19 \%$ 로 가장 높은 항산화 활성을 지닌 균주로 확인되었다(Table 1).

\section{$\beta-G$ lucosidase 활성}

분리주 8종을 대상으로 MRS와 esculin iron 배지를 혼합 하여 MRS-EI를 통해 $\beta$-glucosidase에 대한 활성 여부를 확 인한 결과는 Table 1과 같다. 8종의 분리주 중 SCML 199, SCML 432, SCML 467, SCML 504, SCML 507 등 5종의 분리주가 타 균주와 비교하여 활성이 높은 것으로 확인되었 다. 유산균이 생산하는 효소 중 $\beta$-glucosidase는 배당체 화 합물을 유리시키는 효소로 알려져 있으며, 특히 전통 발효 식품의 주 원료로 사용되는 대두의 isoflavone은 일반적으 로 배당체의 형태로 존재하는데 발효를 통해 미생물이 생성 하는 B-glucosidase에 의해 유리아미노산으로 분해되고 분 해된 유리아미노산은 diadzein과 genistein 등으로 전환되어 체내 장에 흡수되고 항암에 효과 또한 있다고 보고되고 있다(26). 따라서 $\beta$-glucosidase에 대한 활성을 갖는 균주를 활용하여 전통발효식품을 제조할 경우 종균의 가치는 크게 증진될 것으로 기대되며, 앞선 항균활성, biogenic amine 생성 유무, 항산화 활성 등에 높은 활성을 갖고 $\beta$ -glucosidase에 대한 활성도 우수한 SCML 432를 전통발효 식품에 활용 가능한 종균으로 최종 선정하였다.

\section{API ZYM kit을 이용한 SCML 432의 효소 활성}

최종 선별한 SCML 432의 다양한 세포외 효소의 생성 여부를 확인하기 위해 API ZYM kit을 이용하여 분석한
결과는 Table 4 와 같다. SCML 432는 esterase, esterase lipase 의 활성을 갖고 있어 지질에 대한 가수분해 효소로 인해 소화 효과 증진에 유용할 것으로 판단되며, protease 효소인 leucin arylamidase, valine arymidase에 대한 활성을 지니고 있는 것을 확인하였다. 또한, lactose를 glucose와 galactose 로 분해하는데 관여하는 galactosidase 효소에 대한 활성이 나타나 식단 내 칼슘 부족으로 인해 한국인 10 명중 7 명이 지니는 유당불내증에 대한 발병 감소에도 영향을 줄 수 있는 것으로 확인되었다. 이외에도 유해 물질이 체내에 유 입되었을 경우 간에서 gluculonic acid와 결합하여 독성을 일으키며 이로 인해 장내 세균에 의해 암이 유발된다고 보고(27)된 $\beta$-glucurnidase에 대한 활성을 지니지 않아 발암 에 대한 안전성 또한 확인되어 향후 SCML 432 를 활용한 식품 내 종균으로서 다양한 분야에 활용이 가능할 것으로 판단된다.

\section{항생제 감수성}

항생제는 식품과 의약품 등 다양한 산업 분야에 사용되 고 있는 물질로 사람의 경우 음식물의 섭취를 통해 쉽게 체내 유입이 되어 미생물을 주원료로 하는 제품에 항생제에 대한 내성이 없을 경우 치료 목적으로 사용된 항생제에 의해 기능성 저해 및 미생물의 사멸로 인해 제 역할을 수행 하기 어려워 종균을 개발하는 단계에서 유산균의 경우 중요 한 확인 요소로 인식되고 있다(28). 따라서 최종 선별 균주 SCML 432에 대한 항생제 감수성을 측정한 결과 Table 4와 같이 doxycycline, amocicillin/clavulanic acid, ampicillin, erythromycin에 대하여 생육이 저해되었으며, cephalo-sporin 계의 cephalothin, lincosamid 계열의 lincomycin, quinolones 계열의 ciprofloxcin, norfloxacin과 amino glycoside 계열의 streptomycin, kanamycin 등의 계열에 대한 항생제 내성을 지니고 있음을 확인하였다. 이러한 결과는 Jeon 등(28)에 따르면 Lactobacillus 속 균주가 항생제에 대한 내성을 지닐 경우 장내 세균군으로 전이가 가능하며, 항생제 오남용으 로 인한 장내 젖산균의 활동이 저해되는 가능성을 갖는다고 보고되고 있어 식품내 종균으로 사용하기 위한 균주 선택 시 중요한 자료로 활용될 수 있을 것이다.

\section{균체 성장 조사}

Fig. 1에서 보는 바와 같이 SCML 432의 최적 균체 성장을 조사하기 위해 MRS 배지에 seed 배양액을 접종하고 4시간 간격으로 배양하여 흡광도 및 건조 균체량을 측정한 결과, 4 시간째부터 생육이 증가하기 시작하여 28시간에 가장 우 수한 생육을 나타내었으며, 이후 점차 감소하였다. 배양 28 시간에 흡광도는 1.9 와 $3.5 \mathrm{~g} / \mathrm{L}$ 의 건조 균체량으로 최대 생육을 보였으며, 따라서 최적 배양 시간을 대수기에서 정 지기에 들어가는 28 시간으로 결정하였다. 이러한 결과는 Jeon(29)이 보고한 $L$ brevis BH-21의 균체 성장과 일치하는 
결과였으며, Jeon 등(28)의 L. brevis HLJ50 균주가 24시간 에 최대 증식을 나타내었다는 결과와 유사함을 확인하였다.
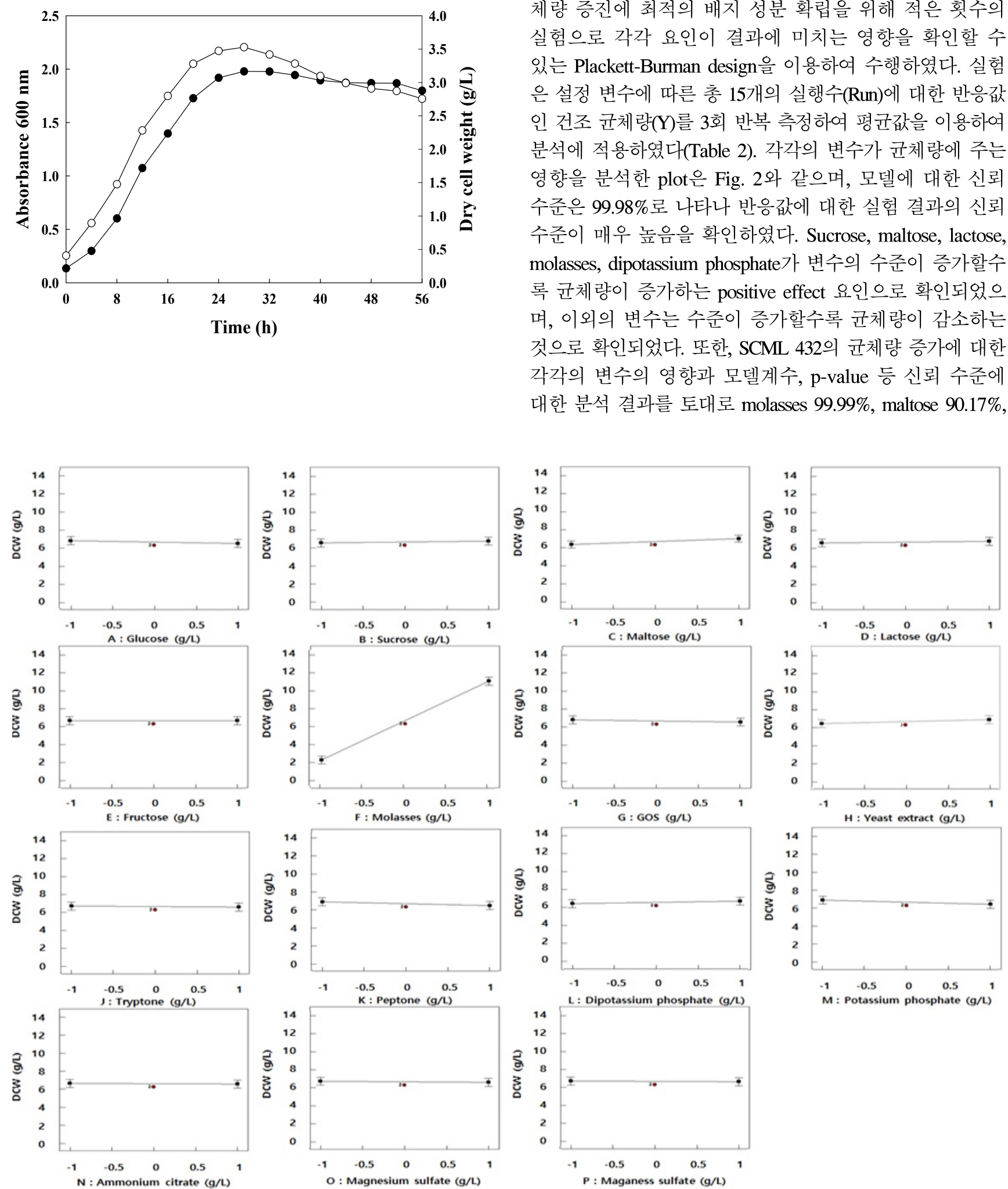

Fig. 2. Main effect plots for media constituents on biomass production of SCML 432.

The greater the slope, the greater the likehood that a main effect is statistically significant. 
yeast extract $76.76 \%$, potassium phosphate $78.64 \%$ 를 주요 인자로 선정하였다(Table 5). 따라서 앞선 실험 변수 수준과 균체량에 대한 plot 결과, 신뢰 수준을 반영하여 molasses, maltose, yeast extract를 SCML 432의 균체량 증진을 위한 최종 배지 성분으로 선별하였다. 특히 탄소원 중 하나인 molasses의 경우 미생물 배양 산업화 적용 시 미생물 생장에 영양분으로 유용하며, $\mathrm{pH} 5.0$ 의 고점성 비정제 사탕수수당 으로 탄소원, 질소원, 인, 염, 철 등과 같은 성분이 풍부하여 최근 대체 탄소원으로 활용도가 높다고 보고(9)되고 있어, 추후 SCML 432의 산업 적용시에도 매우 유용하게 활용될 것으로 판단된다.

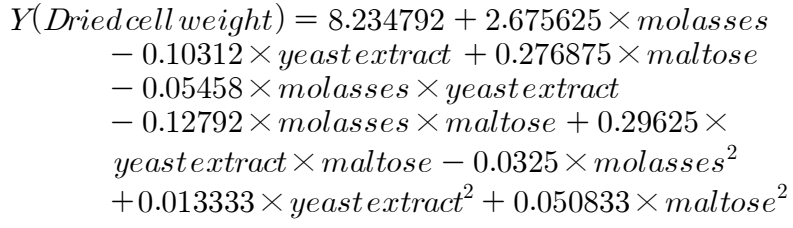

반응값을 반영하여 실험 모델에 대한 분산을 실시한 결 과 결정계수 $\left(\mathrm{R}^{2}\right)$ 는 0.99 로 매우 높은 유의성을 보였으며, 전체 모델에 대한 유의 확률 또한 9.13E-07로 0.05 보다 낮아 가정된 실험 모델이 매우 적합함을 확인하였다. 또한 균체 량 생산에 대하여 개별 또는 변수 상호간의 상호작용에

Table 5. Effects of various medium constituents on biomass production from the results of Plackett-Burman design

\begin{tabular}{|c|c|c|c|c|c|c|}
\hline $\begin{array}{c}\text { Variable } \\
\left(X_{i}\right)\end{array}$ & $\begin{array}{c}\text { Effect } \\
\left(\mathrm{E}_{\mathrm{x} i}\right)\end{array}$ & $\begin{array}{c}\text { Coefficient } \\
\left(\beta_{i}\right)\end{array}$ & Sum of squares & F-value & p-value & $\begin{array}{c}\text { Confidence } \\
\text { level }(\%)\end{array}$ \\
\hline Model & & 6.61 & 392.47 & 50.33 & 0.0002 & 99.98 \\
\hline Glucose & -0.30 & -0.15 & 0.46 & 0.89 & 0.3891 & 61.09 \\
\hline Sucrose & 0.20 & 0.099 & 0.20 & 0.38 & 0.5660 & 43.40 \\
\hline Maltose & 0.65 & 0.33 & 2.14 & 4.11 & 0.0983 & 90.17 \\
\hline Lactose & 0.18 & 0.092 & 0.17 & 0.33 & 0.5930 & 40.70 \\
\hline Fructose & 6.71E-004 & 3.355E-004 & $2.251 \mathrm{E}-006$ & 4.33E-006 & 0.9984 & 0.16 \\
\hline Molasses & 8.78 & 4.39 & 385.73 & 741.98 & $<0.0001$ & 99.99 \\
\hline GOS & -0.25 & -0.12 & 0.30 & 0.58 & 0.4811 & 51.89 \\
\hline Yeast extract & 0.44 & 0.22 & 0.96 & 1.85 & 0.2324 & 76.76 \\
\hline Tryptone & -0.12 & -0.058 & 0.067 & 0.13 & 0.7337 & 26.63 \\
\hline Peptone & -0.42 & -0.21 & 0.88 & 1.69 & 0.2508 & 74.92 \\
\hline Dipotassium phosphate & 0.28 & 0.14 & 0.38 & 0.73 & 0.4311 & 56.89 \\
\hline Potassium phospate & -0.46 & -0.23 & 1.05 & 2.03 & 0.2136 & 78.64 \\
\hline Ammonium citrate & -0.073 & -0.036 & 0.026 & 0.051 & 0.8306 & 16.94 \\
\hline Magnesium sulfate & -0.012 & -0.062 & 0.077 & 0.15 & 0.7164 & 28.36 \\
\hline Manganese sulfate & -0.079 & -0.039 & 0.031 & 0.060 & 0.8169 & 18.31 \\
\hline Standard deviation & \multicolumn{2}{|r|}{0.69} & \multicolumn{2}{|c|}{ Press ${ }^{1)}$} & \multicolumn{2}{|c|}{63.05} \\
\hline Mean & \multicolumn{2}{|r|}{6.57} & \multicolumn{2}{|c|}{$\mathrm{R}$ - square } & \multicolumn{2}{|c|}{0.9927} \\
\hline Coefficient of variation & \multicolumn{2}{|r|}{10.57} & \multicolumn{2}{|c|}{ Adjusted R - square } & \multicolumn{2}{|c|}{0.9743} \\
\hline
\end{tabular}

${ }^{1)}$ The predicted residual sum of squares for the model.

\section{Central composite design을 이용한 배지 성분의 농도 최적화}

$\mathrm{PBD}$ 모델을 통해 선별된 molasses $\left(\mathrm{X}_{1}\right)$, yeast extract $\left(\mathrm{X}_{2}\right)$, maltose $\left(\mathrm{X}_{3}\right)$ 의 최적 농도를 결정하기 위해 $\mathrm{CCD}$ 모델을 설 정하고 분석을 실시하였다. 5 개의 수준에서 실험 계획을 수립하고 건조 균체량을 측정하여 반응값(Y)을 설정하였 으며, 중심점 2 개를 포함한 총 16 개의 실험구간에서 진행하 였다. 각각의 종속 변수에 대한 반응값은 Table 3에 나타내 었고, 건조 균체량에 대한 회귀 방정식은 아래와 같다.
대한 수치를 나타내는 변동계수(CV, coffecient of variation) 도 3.05 로 변수간 상호 작용이 매우 높음을 확인하였다 (Table 6). 3 개의 변수 중 하나의 독립변수를 최대점에 고정 하고 나머지 2 개의 변수를 이용해 3 차원의 형태로 교호 작용을 확인하여 변수별 영향을 확인한 결과를 Fig. 3에 나타내었으며, 실험 범위 내에서 molasses와 maltose의 경우 첨가량이 증가할수록 균체량이 증가함을 확인하였다. 최종 적으로 중심합성 계획법을 통해 예측된 각 변수의 최적 농도는 molasses $5.5 \%$, yeast extract $1.5 \%$, maltose $2.0 \%$ 로 예측되었으며, 이때의 최대 균체 생성량은 $11.2 \mathrm{~g} / \mathrm{L}$ 로 예측 되었다. 
Table 6. Analysis of variance (ANOVA) of central composite design for improving biomass of L. brevis SCML 432

\begin{tabular}{|c|c|c|c|c|c|c|c|}
\hline Source & Coefficient estimate & Sum of squares & Degree of freedom & Mean square & Standard error & F-value & $\begin{array}{c}\text { p-value } \\
\text { Prob }>\mathrm{F}^{1)}\end{array}$ \\
\hline Model & 8.234792 & 116.9112 & 9 & 12.99014 & 0.166718 & 204.4687 & $9.13 \mathrm{E}-07$ \\
\hline $\mathrm{X}_{1}$-Molasses & 2.675625 & 114.5435 & 1 & 114.5435 & 0.063013 & 1802.95 & $1.14 \mathrm{E}-08$ \\
\hline $\mathrm{X}_{2}$-Yeast ext. & -0.10312 & 0.170155 & 1 & 0.170155 & 0.063013 & 2.678292 & 0.15284 \\
\hline $\mathrm{X}_{3}$-Maltose & 0.276875 & 1.226553 & 1 & 1.226553 & 0.063013 & 19.30632 & 0.004599 \\
\hline $\mathrm{X}_{1} \mathrm{X}_{2}^{2)}$ & -0.05458 & 0.023834 & 1 & 0.023834 & 0.089115 & 0.375154 & 0.562686 \\
\hline $\mathrm{X}_{1} \mathrm{X}_{3}$ & -0.12792 & 0.130903 & 1 & 0.130903 & 0.089115 & 2.060455 & 0.201176 \\
\hline $\mathrm{X}_{2} \mathrm{X}_{3}$ & 0.29625 & 0.702113 & 1 & 0.702113 & 0.089115 & 11.05147 & 0.015918 \\
\hline$X_{1}^{2}$ & -0.0325 & 0.0169 & 1 & 0.0169 & 0.063013 & 0.266011 & 0.624467 \\
\hline $\mathrm{X}_{2}^{2}$ & 0.013333 & 0.002844 & 1 & 0.002844 & 0.063013 & 0.044773 & 0.839427 \\
\hline $\mathrm{X}_{3}^{2}$ & 0.050833 & 0.041345 & 1 & 0.041345 & 0.063013 & 0.650775 & 0.45062 \\
\hline Residual & & 0.381187 & 6 & 0.063531 & & & \\
\hline Lack of Fit & & 0.381137 & 5 & 0.076227 & & 1524.548 & 0.019442 \\
\hline Pure Error & & $5 \mathrm{E}-05$ & 1 & $5 \mathrm{E}-05$ & & & \\
\hline Cor. Total ${ }^{3)}$ & & 117.2924 & 15 & & & & \\
\hline & Standard deviation & & 0.25 & & Press ${ }^{4)}$ & & 3.09 \\
\hline & Mean & & 8.27 & & R-square & & 0.99 \\
\hline \multirow{2}{*}{\multicolumn{2}{|c|}{ Coefficient of variation }} & & 3.05 & & Adjusted R-square & & 0.99 \\
\hline & & & & & Adequate precision & & 53.710 \\
\hline
\end{tabular}

Response model was suggested quadratic model through the lack of fit tests.

${ }^{1)} \mathrm{P}$-value, probability distribution value. $\mathrm{p}$-value less than 0.05 indicate that the term is significant.

${ }^{2)} X_{1} X_{2}, X_{1} X_{3}, X_{2} X_{3}$ represent the interaction effect of variables $X_{1}, X_{2}$, and $X_{3} . X_{12}, X_{22}$, and $X_{32}$ are the squared effects of the variables.

${ }^{3)}$ Cor Total, corrected total sum of squares.

${ }^{4)}$ Press, the predicted residual sum of squares for the model.

\section{Validation 분석에 의한 실험 모델 검증}

반응표면 분석법을 통해 예측된 최적 배지에서 $L$ brevis SCML 432의 균체 성장을 검증하기 위해 최적 배지와 대조 구로 유산균 기본 배양 배지인 MRS 액체 배지에 SCML 432 배양액 $5 \%$ 를 접종하여 동일 조건에서 배양하여 건조 균체량을 측정 후 비교하였다(Fig. 4). 측정 결과 최적 조건 에서 SCML 432 의 균체량은 $11.3 \pm 0.06 \mathrm{~g} / \mathrm{L}$ 로 $\mathrm{CCD}$ 결과로 예측된 $11.2 \mathrm{~g} / \mathrm{L}$ 의 오차 범위 내 결과값을 확인하였으며,
최적화를 수행하기 이전 대조구 $3.5 \pm 0.1 \mathrm{~g} / \mathrm{L}$ 와 비교하여 $7.8 \mathrm{~g} / \mathrm{L}$ 증가하여 약 3.2 배의 균체량이 증가한 결과를 확인 하였다(Fig. 4). Molasses를 대체 탄소원으로 이용할 경우 유산균의 균체량 증진뿐만 아니라 lactic acid의 생성량도 증가한다고 보고되고 있으며(30), 특히 $\mathrm{Bae}(31)$ 는 기초 탄 소원으로 molasses를 사용한 배지에 가장 높은 생균수 생산 효율을 나타냈고, 다음으로 maltose로 나타났으며, $L$. plantarum SK1305의 항균력 또한 증가하였으며, SCML
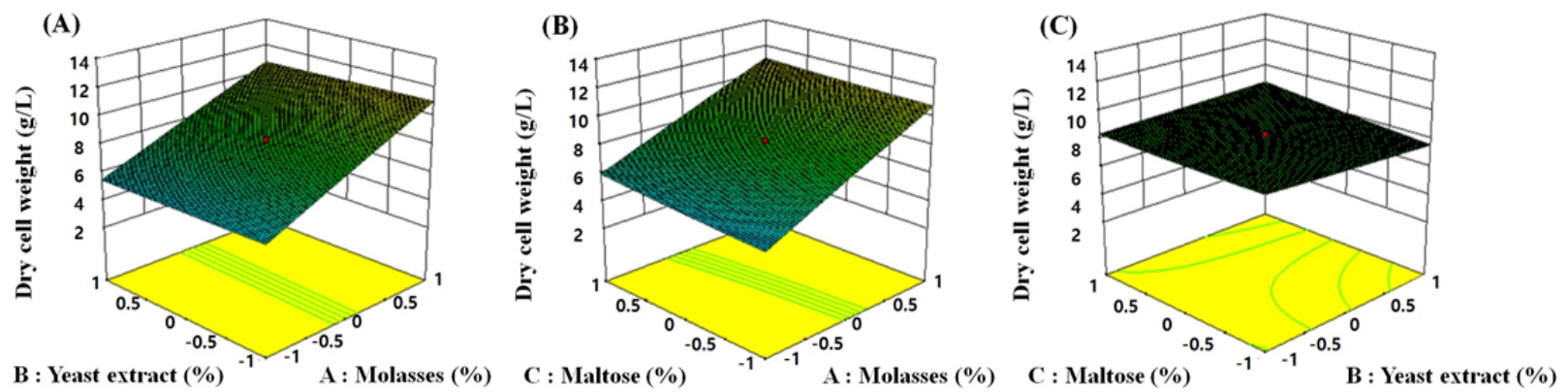

Fig. 3. Three-dimensional response surface plot for maximum biomass production of $L$. brevis SCML 432 at varying concentrations of: (A) molasses $\left(\mathrm{X}_{1}\right)$ and yeast extract $\left(\mathrm{X}_{2}\right)$, (B) molasses $\left(\mathrm{X}_{1}\right)$ and maltose $\left(\mathrm{X}_{3}\right)$, (C) yeast extract $\left(\mathrm{X}_{2}\right)$ and maltose $\left(\mathrm{X}_{3}\right)$. 
432 또한 molasses와 maltose가 주 요인으로 선택되어 기능 성도 증가하는 유사한 결과를 확인하였다.

결론적으로 본 연구에서는 메주로부터 발효식품 산업에 활용하기 위한 유산균을 분리하고, 식품 유해미생물에 대 한 항균활성, biogenic amine 및 유해 물질에 대한 생성여부, 항산화 활성과 같은 기능성 분석을 통해 가장 우수한 유산 균을 선별하여 이를 산업화에 적용하기 위한 배지 성분 및 농도에 대한 최적화를 확립하여 향후 기능성 식품 및 전통 발효식품의 제조에 종균으로 활용 가능하며 수입 균주 의 대체 또한 가능할 것으로 판단된다.

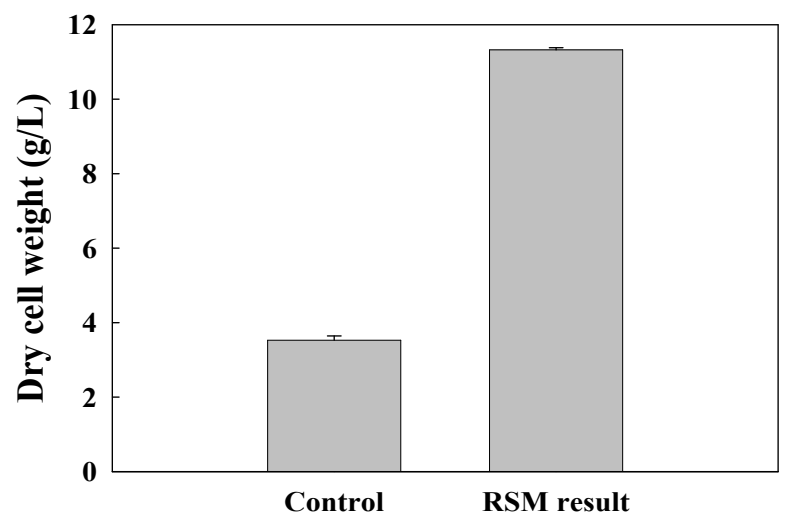

Fig. 4. The comparison of MRS (basal) and optimal culture broth after incubation for $28 \mathrm{~h}$.

The experiments were carried out in triplicate $(\mathrm{p}<0.05)$.

\section{요 약}

본 연구에서는 재래식으로 제조된 전통 메주로부터 상업 적으로 이용 가능하며, 발효식품 산업에 스타터로서 활용 하기 위해 안전성과 기능성이 우수한 Lactobacillus 속 균주 를 선발하고자 하였다. 순창군에서 제조된 메주 시료 180종 으로부터 Lactobacillus 속 균주 407종을 1차 분리하고, 발효 식품 산업의 스타터로 사용하기 위하여 Bacillus cereus 균 주에 대한 억제 효과와 biogenic amine을 생성여부, 용혈성, 유해대사산물 및 유해효소를 생성하지 않는 유산균 8종을 1 차 선별하였다. 또한 분리주의 항산화 활성과 $\beta$-glucosidase 활성을 측정하여 Lactobacillus brevis SCML 432를 최종 선별하였고, SCML 432의 효소 활성과 항생제 감수성을 조사하여 종균으로서의 활용 가능성을 검증하였다. 산업적 적용을 위하여 발효 시간에 따른 균체 성장을 조사한 결과 배양 후 28시간에서 최대 균체량인 $3.4734 \mathrm{~g} / \mathrm{L}$ 의 건조 균체 량을 확인하였고, 이를 기반으로 산업적 적용을 위한 배지 성분을 확립하기 위해 반응표면분석법으로 PlackettBurman design(PBD)와 central composite design(CCD) 방법 을 사용하여 최적화를 수행하였다. 먼저 배지 조성을 확립 하기 위해 $\mathrm{PBD}$ 는 탄소원 6종, 질소원 4종, 무기질 3종, 기타
미량원소 2 종을 이용하여 총 15 개의 요소에 대하여 실험 계획을 수립하였고, 이 중 선별된 배지 조성으로는 molasses, yeast extract, maltose 등 3 개의 요인이 예측되었다. PBD에 서 선정된 3종의 요소를 대상으로 균체량 증가에 대한 성분 의 최적 농도를 $\mathrm{CCD}$ 를 통해 확인한 결과 molasses $5.5 \%$, yeast extract $1.5 \%$, maltose $2.0 \%$ 로 이때 최대 균체량은 11.2 $\mathrm{g} / \mathrm{L}$ 로 예측되었다. 모델의 검증을 통하여 예측된 모델과 실제 결과가 유의함을 확인하였으며, 기본 배.양 배지와 비교하였을 때 균체량이 $3.5 \mathrm{~g} / \mathrm{L}$ 에서 $11.3 \mathrm{~g} / \mathrm{L}$ 로 약 3.2 배 증가하였다. 향후 기능성 식품 및 전통 발효식품 제조를 위한 종균으로 활용하기 위해서는 각각의 식품에 대한 기능 성 및 제조 공정 연구가 필요하지만, 본 연구를 통해 국내 토종 발효 유산균도 다양한 기능성 및 안전성을 지니며, 최적 조건 확립을 통해 산업화 적용을 위한 기반 및 가능성 을 확인하였다.

\section{감사의 글}

이 논문은 2018년도 정부(과학기술정보통신부)의 재원 으로 한국연구재단-전통문화융합연구사업의 지원을 받아 수행된 연구임(No. 2016M3C1B5907049).

\section{References}

1. Gibbs BF, Zougman A, Masse R, Mulligan C (2004) Production and characterization of bioactive peptides from soy hydrolysate and soy-fermented food. Food Res Int, 37, 123-131

2. Kim SS, Lee JH, Ahn YS, Kim JH, Kang DK (2003) A fibrinolytic enzyme from Bacillus amyloliquefaciens D4-7 isolated from Chungkook-jang, It's characterization and influence of additiveds on thermostability. Korean J Microbiol Biotechnol, 31, 271-276

3. Yoo JY, Kim HG, Kim WJ (1998) Physico-chemical and microbiological changes of traditional Meju during fermentation in Kangweondo area. Korean J Food Sci Technol, 30, 908-915

4. Lee NH, Jo EJ, Oh SW, Hong SP (2012) Study on the hurdle technique for the reduction of Bacillus cereus spores in Doenjang and Gochujang. J Korean Soc Food Sci Nutr, 41, 1842-1846

5. Kim C, Hung YC, Brackett RE (2000) Efficacy of electrolyzed oxidizing (EO) and chemically modified water on different types of foodborne pathogens. Int $\mathbf{J}$ Food Microbiol, 61, 199-207 
6. Lee JY, Shim JM, Liu X, Yao Z, Lee KW, Cho KM, Kim GM, Shin JH, Kim JS, Kim JH (2016) Inhibition of Bacillus cereus in Cheonggukjang fermented with Bacillus starters with antimicrobial activities. J Korean Soc Food Sci Nutr, 45, 736-745

7. Cho TY, Han GH, Bahn KN, Son YW, Jang MR, Lee $\mathrm{CH}$, Kim SH, Kim DB, Kim SB (2006) Evaluation of biogenic amines in Korean commercial fermented foods. Korean J Food Sci Technol, 38, 730-737

8. Alvarez MA, Moreno-Arribas MV (2014) The problem of biogenic amines in fermented foods and the use of potential biogenic amine-degrading microorganisms as a solution. Trends Food Sci Technol, 39, 146-155

9. Yang HJ, Jeong SJ, Jeong SY, Heo JH, Choi NS, Jeong DY (2016) Screening of non-biogenic-amine-producing Bacillus subtilis and medium optimization for improving biomass by the response surface methodology. J Life Sci, 26, 571-583

10. Lilly DM, Stillwell RH (1965) Probiotics: Growth promoting factors produced by microorganisms. Science, 147, 747-748

11. Bang JH, Shin HJ, Choi HJ, Kim DW, Ahn CS, Jeong YK, Joo WH (2012) Probiotic potential of Lactobacillus isolates. J Life Sci, 22, 251-258

12. Liu SP, Yu JX, Wei XL, Ji ZW, Zhou ZL, Meng XY, Mao J (2016) Sequencing-based screening of functional microorganism to decrease the formation of biogenic amines in Chinese rice wine. Food Control, 64, 98-104

13. Yang HJ, Jeong SJ, Jeong SY, Ryu MS, Jeong DY (2018) Isolation of biogenic amine non-producing Lactobacillus brevis SBB07 and its potential probiotic properties. J Life Sci, 28, 68-77

14. Gao X, Qiao S, Lu W (2009) Determination of an economical medium for growth of Lactobacillus fermentum using response surface methodology. Lett Appl Microbiol, 49, 556-561

15. Kim DW, Cho SB, Kim YH, Lee SD, Jung HJ, Kim SH, Cho KH, Sa SJ, Kim IC, Won MY, Kim SO, Kim SK (2012) Screening of effective medium composition for the cultivation of Lactobacillus plantarum and Lactobacillus reuteri using statistical methods. J Life Sci, 22, 575-581

16. Jeong SJ, Shin MJ, Jeong SY, Yang HJ, Jeong DY (2014) Characteristic analysis and production of short-ripened Korean traditional soy sauce added with rice bran. J Korean Soc Food Sci Nutr, 43, 550-556

17. Ryu MS, Yang HJ, Kim JW, Jeong SJ, Jeong SY, Eom
JS, Jeong DY (2017) Potential probiotics activity of Bacillus spp. from traditional soybean pastes and fermentation characteristics of Cheonggukjang. Korean J Food Preserv, 24, 1168-1179

18. Lee SJ, Lee MJ, Jung JE, Kim HJ, Shambhunath B (2012) In vitro profiling of bacterial influence and herbal applications of Lonicerae flos on the permeability of intestinal epithelial cells. J Korean Soc Food Sci Nutr, 41, 881-887

19. Stenfors Arnesen LP, Fagerlund A, Granum PE (2008) From soil to gut: Bacillus cereus and its food poisoning toxins. FEMS Microbiol Rev, 32, 579-606

20. Cha HA, Chung D, Hong SW, Chung KS (2014) Purification and characterization of an antimicrobial substance from Bacillus subtilis $\mathrm{HH} 28$ antagonistic to Bacillus cereus. Korean J Microbiolol Biotechnol, 42, 393-401

21. Cho TY, Han GH, Bahn KN, Son YW, Jang MR, Lee $\mathrm{CH}$, Kim SH, Kim DB, Kim SB (2006) Evaluation of biogenic amines in Korean commercial fermented foods. Korean J Food Sci Technol, 38, 730-737

22. Maijala R, Eerola S (1993) Contaminant lactic acid bacteria of dry sausages produce histamine and tyramine. Meat Sci, 35, 387-395

23. Lim ES (2017) Incubation conditions affecting biogenic amines degradation of probiotic lactic acid bacteria. Korean J Microbiol, 53, 273-285

24. Lee Y, Chang HC (2008) Isolation and characterization of kimchi lactic acid bacteria showing anti-Helicobacter pylori activity. Korean J Microbiolol Biotechnol, 36, 106-114

25. Park SY, Lee SG, Park SI, Kim IY, Jeong YH, Yu SR, Shin SC, Kim MS (2015) Antioxidant activity of Korean traditional soy sauce fermented in Korean earthenware, Onggi, from different regions. J Korean Soc Food Sci Nutr, 44, 847-853

26. Cho YH, Imm JY, Kim HY, Hong SG, Hwang SJ, Park DJ, Oh SJ (2009) Isolation and partial characterization of isoflavone transforming Lactobacillus plantarum YS712 for potential probiotic use. Korean J Food Sci Ani Resour, 29, 640-646

27. Cole CB, Fuller R, Carter SM (1989) Effect of probiotic supplements of Lactobacillus acidophilus and Bifidobacterium adolescentis 2204 on $\beta$-glueosidase and $\beta$-glueuronidase activity in the lower gut of rats associated with a human faecal flora. Microb Ecol Health Dis, 2, 223-225 
28. Jeon CP, Kim YH, Lee JB, Jo MS, Shin KS, Choi CS, Kwon GS (2010) Physiological characteristics and angiotensin converting enzyme inhibitory activity of Lactobacillus brevis HLJ59 isolated from salted shrimp. Korean J Microbiol, 46, 9-14

29. Jeon JH (2004) Production of $\gamma$-aminobutyric acid (GABA) by immobilization of lactic acid bacteria isolated from salt fermented anchovy. Ph D Thesis, Kyungsung University, Korea, p 34-36
30. Srivastava AK, Tripathi AD, Jha A, Poonia A, Sharma (2015) Production, optimization and characterization of lactic acid by Lactobacillus delbruechii NCIM 2025 from utilizing agro-industrial byproduct (cane molasses). J Food Sci Technol, 52, 3571-3578

31. Bae C (2008) Antagonisterial effect of Lactobacillus plantarum SK1305 and optimum media composition determined by Plackett-Burman design. MS Thesis, Konkuk University, Korea, p 19-23 